\title{
DIE IMMUNOLOGIE VAN HIV
}

Maartin van der Walt

Departement Biochemie

Potchefstroomse Universiteit vir CHO

POTCHEFSTROOM

\begin{abstract}
Some characteristics of HIV, a retrovins which is the causative agent of AIDS, and the immune system, are discussed in this paper to help one understand the mechanism and development of this devastating viral infection.

The conclusion of this paper is that a suirable vaccine or drug if and whenever it becomes available, is not the answer to this fatal disease. The only solution is to be found in educating the youth to implement Scriptural values in their life styles.
\end{abstract}

\section{INLEIDING}

Verworwe immuniteitsgebreksindroom, (VIGS), is een van die siektes waaroor tans baie geskryf en gepraat word. Ten spyte van die baie inligting wat deurgegee word, is daar nog baie vrae en onduidelikhede oor hierdie saak. Daarom word daar gepoog om in hierdie artikel 'n oorsig te gee oor die herkoms en ontwikkeling van die siekte vanuit 'n biologiese oogpunt.

Dit is die ongelukkige feitelike situasie dat ons kinders alreeds met die abnormale gekonfronteer word (byvoorbeeld plakkate om die gebruik van kondome aan te moedig in die veldtog teen VIGS) terwyl hulle nog nie eens insae behoort te hê in die normale intieme seksverhoudinge nie. Geweldig baie tyd en geld word spandeer om die liggaam gesond te hou terwyl die gees van die mens verwaarloos word. Die uitgangspunt van hierdie artikel is dus om vanuit 'n biologiese oogpunt inligting oor te dra wat ouers kan gebruik om hulle kinders te lei in die kennis van regte verhoudings (Curtis et al., 1989:1240-1245). Hierdeur moet hulle in staat gestel word om die verkeerde vroegtydig te onderskei en sodoende seksueel rein te bly (1 Tess. 4:3-65). Oor ' $n$ aantal jare van intensiewe beradingsessies met huwelikspare het dit weer eens duidelik geword dat sonde op die seksuele vlak nie net onmiddellike implikasies het nie, maar ook op die lang termyn 'n geweldige invloed op verhoudinge het, veral binne 'n verhouding 
waarin 'n huwelik gesluit word. (Vir 'n volledige bespreking hiervan vergelyk De Bruyn, 1990.)

\section{VIGS}

Verworwe immuniteitsgebreksindroom beskryf 'n siektestoestand wat die gevolg is van omgewingsfaktore (verworwe) en is dus nie oorgeërf of geneties vasgele is nie. Die siekte impliseer ook dat die verworwe probleem die immune- of verdedigingsisteem betrek deurdat hierdie sisteem gebrekkig raak om die liggaam te beskerm. VIGS is dus die komplekse siektebeeld wat die gevolg is van 'n aanvanklike infeksie deur 'n virus bekend as HIV (Human Immunodeficiency Virus).

Die eerste VIGS-gevalle is in 1981 aangemeld. Aan die einde van 1982 was daar aanduidings dat die siekte deur middel van bloedoortappings oorgedra word. Die betrokke faktor het egter geheim gebly. Verskeie virusse is verdink, byvoorbeeld Hepatitis B, Epstein Barr, Cytomegalo en andere, maar dit is eers in 1983 en finaal in 1984 dat die virus geïdentifiseer en gekarakteriseer is as HIV-1, 'n virus naverwant aan HTLV-1, wat limfosietkanker kan veroorsaak (Girard, 1988:745-763).

\section{$2.1 \quad$ HIV}

HIV vorm deel van die virusklas bekend as die retrovirusse. Die onderskeidende kenmerk van hierdie groep is die feit dat hierdie virusse in staat is om hulle genetiese materiaal, wat anders as in die geval van die menssel (eukariotiese seltipe) uit RNA bestaan, terug te omvorm na DNA. Laasgenoemde stem struktureel nou ooreen met die genetiese materiaal van die menssel en kan in hierdie vorm ingebou word en uiteindelik ' $n$ integrale deel vorm (bekend as die provirus) van die genetiese materiaal van 'n geïnfekteerde sel. 'n Teruguloei (retro) van informasie het dus plaasgevind naamlik van RNA na DNA, vandaar die naam retrovirus.

Die retrovirusse word op grond van morfologie en morfogenese in drie subklasse ingedeel, naamlik die oncoviridae (tipe B, C en D) (wat onder andere 'n sekere tipe mensleukemie kan veroorsaak - HTLV-1), die spumaviridae en die lentiviridae. HIV val onder die lentiviridae en hierdie subklas het bo en behalwe morfologiese ooreenkomste ook 'n kenmerkende genoomrangskikking (erflikheidsmateriaal) en biologiese eienskappe. Hierdie virusse bevat die standaard retrovirusgene (eenhede wat op die genoom voorkom en inligting vir spesifieke proteïenstrukture of reguleringsfunksie dra) bekend as gag, pol en env. Gag is die afkorting vir 'n groepspesifieke antigeen en verwys na proteiene in die virusstruktuur wat binne die virusgroep ooreenstem. $\mathrm{Pol}$ 
staan vir RNA-afhanklike DNA polimerase en verwys na die virus-ensiem wat in staat is om die retrotranskripsie, dit wil sè van virus RNA na DNA, te behartig. Die dee van die virusgenoom wat bekend staan as env bevat die inligting vir die proteiene wat in die kapsel (omhulsel) van die virus voorkom (Desrosiers, 1988:607-625). Die lentivirusse beskik oor addisionele gene wat onder andere regulerende eienskappe vertoon. Vyf van hierdie gene is reeds angetoon en staan bekend as tat (transaktiveerder), rev (reguleer modifiserings van virusproteïene), nef (negatiewe regulering van virusuitdrukking), vif en $v p u$ (noodsaaklike virusmorfogenese en verandering) en vpr (onbekende funksie) (Varmus, 1988:1055-1062; Cullen en Greene, 1989:423-426).

Twee definitiewe HIV-lyne is reeds geïsoleer wat grootliks ooreenstem met HIV wat by pasiënte in Wes-Afrika geïsoleer is. Hierdie virus het maar ongeveer 'n $50 \%$ ooreenstemming in nukleotiedvolgorde (boustene van erflikheidsmateriaal) met die viruslyn wat in Sentraal-Afrika, Europa en die VSA voorkom. Die Wes-Afrikalyn staan as HIV-2 bekend, terwyl dié van die VSA en aanverwante lande as HIV-1 beskryf word. 'n Virus soortgelyk aan HIV maar wat by sekere primate aangetref word, staan weer as SIV (simian immune deficiency virus) bekend. Laasgenoemde vertoon weer 'n 50\% homologie in sy erflikheidsmateriaal met dié van HIV-2. Aanvanklik was daar' $n$ sterk gebiedsgebonde voorkoms van HIV-1 en HIV-2, maar sedertdien het die HIV-1 sterk na vore gekom in Wes-Afrika en is besig om HIV-2 infeksie te oorskadu (Essex \& Kanki, 1988:44-51). Behalwe waar anders vermeld, handel die verdere bespreking oor HIV-1.

Noukeurige ondersoeke van verskillende HIV- (sowel HIV-1 as HIV-2) isolate (selfs uit dieselfde individue) dui daarop dat HIV, soos vele ander RNA-virusse, oor 'n geweldige genetiese diversiteit beskik, in so 'n mate dat daar selfs van kwasiespesies ge praat word (Fischer et al., 1988:444-447; Meyerhans et al., 1989:901-910). Die genetiese variasie is die gevolg van die feit dat een verkeerde nukleotiedinbouing plaasvind wanneer 'n virus vermeniguuldig word. Aangesien die HIV-genoom oor ongeveer 10000 nukleotiede beskik, beteken dit een verkeerde invoegsel (mutasie) per 10000 nukleotiede (Dougherty \& Temin, 1988:2817-2822). Hierdie is 'n geweldige mutasietempo wat groot implikasies inhou vir doeltreffende vaksienbereiding. Hierdie probleem word beklemtoon as in ag geneem word dat die mutasievoorkoms, veral in die env en aanverwante gebiede gekonsentreer is (Jones et al., 1988:1101-1114; Trono et al., 1989:113-120; Schüpbach, 1989:32). 'n Verdere komplikasie is dat daar ook mutasies plaasvind in daardie deel van die HIV-genoom wat die inligting bevat vir die ensiem wat die virus-RNA na DNA verander (omgekeerde transkriptase-ensiem). 'n Sekere groep teenvirusmiddels beïnvloed die werking van hierdie ensiem, byvoorbeeld die bekende AZT (zidovudien of 3'-azido-3'-deoksitimidien). As gevolg van die mutasies binne die betrokke ensiem se geen, raak die virus weerstandbiedend teen AZT met noodwendige nadelige gevolge vir die pasiënt (Larder \& Kemp, 1989:1155-1158). 


\section{HIV-positief}

Die verloop van VIGS kan beter verstaan word indien die immuunsisteem van die liggaam van naderby bekyk word. In hooftrekke kan die selle wat betrokke is in die immuunsisteem in drie groepe ingedeel word, naamlik die limfosiete, fagosiete en ondersteuningselle.

Die limfosiete sluit die sogenaamde B-en T-selle in. Beide hierdie seltipes is betrokke by die spesifieke uitkenning van liggaamsvreemde elemente soos virusse, bakterieë, vreemde selle (soos by bloedoortapping of weefseloorplanting) en getransformeerde selle (kankerselle). In die geval waar B-selle 'n liggaamsvreemde komponent herken en geaktiveer word, verander hierdie seltipe tot plasmaselle wat massas immunoglobuliene (tipe proteien ook bekend as teenliggaampies) vervaardig en vrystel (tot 2000 per sekonde per sel) (Jerne, 1973:53). Aangesien 'n persoon voortdurend met vreemde organismes gekonfronteer word (deur byvoorbeeld die lugweë en spysverteringstelsel), is hierdie proses van teenliggaamvorming voortdurend aan die gang. Elke milliliter bloed van 'n persoon bevat ongeveer $5 \times 10^{16}$ teenliggaampies. Wat nog meer indrukwekkend is, is die feit dat hierdie teenliggaampies elk twee bindingspunte bevat wat spesifiek aan 'n komplementêre struktuur (epitoop) op die liggaamsvreemde komponent (antigeen) bind. ' $n$ Voorbeeld hiervan is 'n virus. Wanneer 'n nuwe virus die liggaam binnedring, mag dit 'n sel infekteer en begin vermenigvuldig. In hierdie proses word die immuunsisteem met hierdie virus of met van sy vrye proteïene gekonfronteer. Aangesien B-selle oor reseptore (bindingsmolekule) beskik wat hoogs spesifiek is, sal slegs die B-selle wat aan die virus of sy vrye proteiene kan bind, aangeskakel word. Laasgenoemde verdeel dan en vorm uiteindelik plasmaselle wat teenliggaampies op dieselfde patroon vorm as die oorspronklike reseptore wat spesifiek vir die virus is Tydens die eerste konfrontasie word 'n teenliggaampie vervaardig wat oor spesiale eienskappe beskik wat hom in staat stel om 'n vreemde organisme vinnig en doeltreffend te elimineer. Hierdie tipe of klas teenliggaam staan as IgM (Immunoglobulien M) bekend. As gevolg van hierdie spesiale eienskappe is die tipe teenliggaampie nie so beweeglik nie en skakel die B-selle spoedig oor na die maak van 'n tweede tipe teenliggaampie bekend as IgG (Immunoglobulien G). Uit die totaal van vyf klasse teenliggaampies wat in die liggaam aangetref word, kom hierdie tipe $(\operatorname{IgG})$ in die grootste konsentrasie in die liggaam voor en is dit ook die enigste tipe wat oor die plasenta kan beweeg om sodoende 'n fetus passief te immuniseer.

Uit hierdie bespreking kan nou verduidelik word wat dit beteken as iemand HIV. positief gediagnoseer word: na infeksie met HIV verloop daar 'n tyd waar die immuunsisteem aangeskakel word en uiteindelik oorgaan tot IgG-sintese, spesifiek teen die HIV. Aangesien die meer betroubare algemene toets vir HIV op die teenwoordigheid van IgG (teen HIV) berus, word 'n persoon as HIV-positief (HIV +) 
bestempel sodra die betrokke IgG in die bloed verskyn. Die proses staan dan ook as sero-omskakeling (seroconversion) bekend. Ongelukkig is dit so dat hierdie omskakelingsproses enigiets van twee weke tot selfs meer as drie jaar kan neem. Die implikasies hiervan vir bloedskenkings en bloedoortappings waar van vars bloed gebruik gemaak word, is voor-die-hand-liggend.

Daar is wel meer sensitiewe toetse byvoorbeeld die sogenaamde PCR (Polimerase versterkingsreaksie - polymerase chain reaction), maar dit is gesofisitikeerde toetse en moet deur spesiaal opgeleide personeel uitgevoer word (Bell, 1989:351-355).

Wat die T-selle aanbetref word vyf klasse onderskei. Elke klas het sy eie funksie, byvoorbeeld die Tc-selle wat sitotoksies is en ongewenste selle kan elimineer. Ts-selle het weer die funksie van onderdrukking van die immuunsisteem. Die seltipe waarin ons egter belangstel, is die Th-sel of helper T-sel. Hierdie besondere tipe T-sel vervul 'n sleutelrol in die immuunsisteem deurdat dit onder andere die B-selle help om teenliggame te produseer. Die meeste B-selle benodig die hulp van Th-selle wanneer dit met ' $n$ antigeen in aanraking kom. Die Th-sel (net soos die ander vier klasse T-selle) maak ook van antigeenspesifieke reseptore (baie soos in die geval van die B-selle) gebruik om antigene uit te ken. Wanneer daar byvoorbeeld ' $n$ virus in die liggaam beland, sal die ooreenstemmende B-selle en T-selle wat met die virus kan bind, dit doen en in die proses sal die Th-sel die B-sel stimuleer tot teenliggaamsintese.

Die Th-sel werk in assosiasie met Tc-selle in die herkenning van weefseloorplantings en virusgeïnfekteerde selle. Die Th-selle stel ook limfokiene (proteïene wat ook betrokke is in die kommunikasie tussen selle en deur limfosiete vrygestel word) vry wat makrofage en ander selle kan aktiveer (Roitt et al., 1989:1.8, 4.1-4.10, 8.10-8.11).

Dit is dus duidelik dat indien die Th-selle defektief of afwesig is, soos in die geval van Di George se sindroom, die totale immuunsisteem in duie stort. In so 'n geval kan selfs nie-patogeniese organismes uiteindelik lewensgevaarlik word. Dit is wat in die geval van HIV-infeksie gebeur.

\section{HIV en die immuunsisteem}

Omdat 'n virus nie oor sy eie vermenigvuldigingsapparaat beskik nie moet 'n sel geïnfekteer word scdat die boumateriaal, energie en vermenigvuldigingsapparaat van die sel benut kan word. Daar is verskillende meganismes waardeur virusse selle kan binnedring. Die eerste stap is in elke geval egter die binding van die virus aan die seloppervlak. In hierdie bindingsproses speel reseptore 'n baie belangrike rol omdat dit die toeganklikheid van 'n sel vir 'n spesifieke virus gaan bepaal. In die geval van die 
groep bekend as die picorna-virusse, is dit ook baie mooi angetoon dat die tipe reseptor (bindingspunt op seloppervlak) op die sel bepaal watter tipe selle in die liggaam uiteindelik deur die betrokke virus geïnfekteer sal word (vir 'n oorsig hiervan, vgl. Crowell \& Landau, 1983:1-42). Twee aspekte is van groot belang tydens die bindingsproses, naamlik enersyds die reseptor of bindingsmolekuul op die seloppervlak waaraan die virus bind en andersyds die virusproteïen wat vir die binding verantwoordelik is.

\subsection{Die selreseptor}

Omdat HIV selspesifiek is, beteken dit dat hierdie virus slegs sekere tipes selle sal infekteer. Hierdie groepe selle het 'n proteïen aan die oppervlak in gemeen wat bekend staan as die CD4-antigeen. Selle wat oor hierdie proteïen beskik, staan as $\mathrm{CD} 4$ + selle bekend. CD4 + selle sluit 'n verskeidenheid selle in, maar kan in hoofsaak saam gegroepeer word as die Th-selle en selle van die monosiet/makrofaaglyn.

Die CD4-proteïen, vroeër bekend as die T4-proteïen, bestaan uit 'n enkele peptiedketting en vorm deel van die reseptorkompleks op die selmembraan wat gemoeid is met sel-sel kommunikasie. Daar is nie 'n groot variasie in die struktuur van die CD4proteïen tussen veskillende individue nie. Die CD4-proteien is saamgestel uit $435 \mathrm{ami}$ nosure (Maddon et al., 1985:93-104) waarvan die grootste gedeelte aan die buitekant van die sel geleë is. 'n Gedeelte van die proteïen kom in die membraan van die sel voor terwyl 'n gedeelte van ongeveer 40 aminosure as 'n sitoplasmiese stertgedeelte aan die binnekant van die sel geleë is. Die proteïen oorspan dus die membraan sodat dit in staat is om deur middel van ' $n$ konformasieverandering 'n sein oor te dra van buite die sel (wanneer 'n molekuul daaraan sou bind) na die binnekant van die sel. Die stertgedeelte is op sy beurt weer in verbinding met 'n spesiale ensiem (biologiese katalis) wat, wanneer CD4 van konformasie verander, dit self geaktiveer word om sy gespesialiseerde prosesse binne die sel aan die gang te sit. Hierdie prosesse sluit onder andere modifikasies (veranderings) in wat aan die T-sel reseptor aangebring word (Janeway, 1989:234-238; Sattentau \& Weiss, 1988:631-633; Hurley et al., 1989:407409).

Keer ons nou terug na die buitekant van die sel waar die CD4-proteïen kan assosieer met 'n spesifieke molekule, vind ons normaalweg dat hierdie assosiasie geskied wanneer liggaamselle kommunikeer. Die HIV beskik egter oor 'n proteïen aan sy buiteoppervlak, bekend as gp120. Hierdie proteïen besit'n bindingspunt wat met hoë affiniteit aan die CD4-proteïen kan bind. Die kontak-area tussen die proteïene is baie klein en ongeveer 12 aminosure van CD4 is betrokke (Arthos et al., 1989:469-481). Dit is verder opvallend dat hierdie kontak-area op die virus gp120-molekule moontlik binne 
'n skede geleë is. Die struktuur kan voorgestel word deur gp120 met 'n knopkierie te vergelyk: die knobbel stel die area van gp120 voor wat met $\mathrm{CD} 4$ sal assosieer. Die werklike kontak-area is dan geleë in ' $n$ groefie in die knobbel waarin die bindingsgedeelte (ongeveer 12 aminosure) van CD4 inpas. Hierdie voorstelling bied 'n verklaring vir die feit dat HIV die immuunsisteem so geredelik ontduik aangesien die bindingsarea afgeskerm is en dus nie aanleiding kan gee tot die opwekking van teenliggame teen die betrokke gebied nie. Sou dit wel gebeur, sal die teenliggame wat opgewek word aan hierdie area kan bind om sodoende die virus te verhoed om aan die sel te bind (neutraliseer) en dit te infekteer (Arthos et al, 1989:469-481).

\subsection{Virusindringing}

Wat gebeur nadat die virus aan CD4 gebind het? Dit wil voorkom of HIV nie volgens die normale viropexis of fagositose (selmembraanomsluiting en -inname) die sel binnedring nie, maar wel deur middel van fusie van die virusmembraan met die selmembraam (Stein et al., 1987:659-668; Maddon et al., 1988:865-874). Hierdie meganisme van indringing word moontlik gemaak deurdat die virus oor 'n buitekapsel beskik wat bestaan uit virus-eie proteïene wat ingebed is in ' $n$ selgeroofde membraan (lipiedbasis). Die virus smelt dus letterlik in die sel in en stel sy binnekapsel wat uit virusproteïen en genetiese materiaal bestaan, in die sitoplasma vry. Hierdie viruskernpartikel is 'n stewige struktuur omdat die virusproteïen wat daarin voorkom, verantwoordelik gaan wees vir die oorskryf van die virus se genetiese materiaal: dit is die omvorming van enkelstring-RNA na dubbelstring-DNA, soortgelyk aan dié van die sel. Hierdie kompleks beweeg uiteindelik van die sitoplasma na die selkern waar die virusDNA in die sel-DNA ingebou word (Bowerman et al, 1989:469-478). In hierdie vorm staan die virus nou as 'n provirus bekend (virus-DNA ingebou in die sel-DNA). In hierdie vorm kan die virus nou latent wees vir 'n onbeperkte tyd en is dit ook nie moontlik om vry virus waar te neem nie. Die enigste manier waarop die teenwoordigheid van die virus aangetoon kan word, is deur middel van 'n DNA-analise soos met die PCR-metode. Die infektiwiteit van die provirus bly egter steeds potent omdat enige iets wat die betrokke sel tot seldeling kan stimuleer, dit wil sê die DNA van die sel kan aktiveer, ook die virus-DNA kan aktiveer om sodoende die virus te begin produseer. In die geval van HTLV-1 ('n leukemievirus) wat ook CD4-selle infekteer, lei dié infeksie tot 'n grootskaalse stimulering van T-seldeling met 'n gevolglike oorgroeiing van hierdie selle. In teenstelling hiermee, lei HIV-infeksie tot die lisering van die geïnfekteerde selle, dit is die uitwissing daarvan (Greene et al, 1989:272-277). In die geval van 'n lae frekwensie van HIV-vorming, word vrye gp120 proteïen van die virus in die membraan van die sel aangetref. Dit kan aanleiding gee tot opportunistiese assosiasie met ander CD4-selle om sogenaamde sinsitia te vorm. Hierdie sinsitia kan tot 500 selle betrek wat uit die aard van die samesmelting binne $\mathbf{4 8}$ uur afsterf 
(Dalgleish et al., 1984:763-766; Maddon et al., 1988:871; Rosenberg \& Fauci, 1988:164-174). Op hierdie manier word die Th-sel populasie verminder sodat dit van 'n normale telling van meer as $400(800-1000)$ selle per mikroliter tot minder as 400 daal. Hierdie selle word terselfdertyd aan die einde van die siektetoestand onderdruk (Schüpbach, 1989:54-63; Rosenberg \& Fauci, 1988:167). Hierdie toedrag van sake verklaar dan die feit dat die pasiënte so vatbaar is vir bakteriële, virale en swaminfeksies.

Volledigheidshalwe moet dit genoem word dat die monosiete/makrofage as 'n tipe opbergeenheid vir HIV dien in dié sin dat die selle nie gedood word nie, maar virusse teen 'n konstante tempo produseer. Hierdie verskynsel is waarskynlik toe te skryf aan die voortdurende uitdrukking van 'n spesifieke reguleringsproteïen, (kappa B-spesifieke proteïen) in die kern van die betrokke selgroep wat dan die HIV-gene aktiveer wat tot virusuitdrukking aanleiding gee (Greene $e t$ al., 1989:215-223). 'n Soortgelyke situasie kom voor wanneer HHV-6 (human herpes vinus-6) T-selle ko-infekteer (saam infekteer) met HIV-1. Tydens HHV-6 infeksie word sekere selkernfaktore geïnduseer (aangeskakel) wat HIV-1 uitdrukking bevorder. Die implikasie hiervan is dat gesamentlike infeksie met HHV-6 die verloop van VIGS in so 'n pasiënt bespoedig (Ensoli et al., 1989:3019-3027).

Vrye virus is uit bykans alle moontlike liggaamsvloeistowwe van VIGS-pasiënte geïsoleer, naamlik bloed, semen, vaginale sekresies, melk, speeksel, sweet, trane, serobrospinale vloeistof, amnionvog en urine. Die mees doeltreffende oordrag van die virus is deur middel van bloed (limfosietselle), semen, melk, vaginale sekresies en in die baarmoeder (Schüpbach, 1989:33; Bradbeer, 1989:806-807). Die moontlikheid van oordrag deur middel van trane en sweet is baie gering, maar tog moontlik, want eksperimentele gegewens dui daarop dat dit nie onmoontlik is dat die virus selfs deur die vel gedra kan word nie (Ramirez et al., 1988:901-905; Landor, 1989:489). Oordraging deur die vel is moontlik omdat die selle wat in die epidermis van die vel en slymvliese voorkom, oor reseptore vir die virus beskik. Weer eens moet dit beklemtoon word dat die moontlikheid hiervoor baie gering is, eintlik weglaatbaar klein, maar dat dit teoreties oënskynlik tog moontlik is.

Die hoofmeganisme van HIV-oordrag bly egter deur middel van seksuele kontak, be smette bloed of bloedprodukte en prenatale blootstelling. Die moontlikheid van oordrag deur middel van insekte soos muskiete en weeluise is, alhoewel teoreties moontlik (besmette monddele), in die praktyk heel onwaarskynlik. Die rede hiervoor is dat virusvermenigvuldiging binne hierdie vektore nodig is om die virus effektief te kan oordra. Eksperimente het getoon dat vinusvermenigvuldiging nie in die muskiet of in die weeluis plaasvind nie; derhalwe kom HIV nie in die speeksel van hierdie diere voor nie en kan dus nie soos ander muskietoordraagbare virusse oorgedra word nie. 
Slegs gekontamineerde monddele kan oordraging van die virus bewerkstellig, maar weer eens in die geval van HIV, is die aantal bloedselle in die pasiënt wat geïnfekteer is, so min dat die moontlikheid van oordrag van 'n geïnfekteerde sel op hierdie wyse baie skraal is (Jupp \& Lyons, 1987:171-174; Webb et al., 1989:970-977).

\subsection{Die natuurlike verloop van HIV-infeksie}

$\mathrm{Na}$ die aanvanklike infeksie verloop daar normaalweg een tot drie weke voordat ' $n$ akute siektetoestand ontstaan. Laasgenoemde sluit simptome in wat baie kenmerkend is van 'n griepaanval of mononukleose, byvoorbeeld hoofpyn, duiseligheid, spierpyne, koors, sweet, keelseer, klierswelsel, ensovoorts. (By uitsondering kan 'n veluitslag voorkom wat soms blywend is.) Die toestand is kortstondig en laat die pasiënt oënskynlik blakend gesond agter. In hierdie tyd vind sero-omskakeling ook plaas. Hierna volg 'n tydperk wat asimptomaties is en selfs etlike jare kan duur (gemiddeld ses jaar). In hierdie tydperk kan die persoon van tyd tot tyd die dokter besoek met "gewone" klagtes, maar mettertyd begin die immuunsisteem onderdruk word. Dit gee daartoe aanleiding dat die persoon meer blootgestel is aan patogene organismes met die gevolglike verhoogde vatbaarheid daarvoor. Intussen vind die vergroting van die limfknoppe (kliere) ook plaas (meer as $1 \mathrm{~cm}$ deursnee). Hierdie vergrote kliere is sag en die toestand is permanent, daarom staan dit ook bekend as voortdurende algemene limfadenopatie (persistent generalized lymphadenopathy - PGL). 'n Vergrote milt mag ook ontwikkel.

Die volgende fase wat voorkom, is wanneer die pasiënt VIGS-simptome begin vertoon. Soos reeds verduidelik, is VIGS 'n kombinasie van simptome soos opportunistiese infeksies, tumore (gewasse), neurologiese afwykings, koors, nagsweet, diarree, gewigsverlies, moegheid, mondspru (kenmerkend in baie gevalle), infeksies van die mondholte (van die eerste tekens in baie gevalle), ensovoorts. Bloedtoetse op hierdie stadium sal 'n verlaging in die hoeveelheid Th-selle aantoon, asook afwykings van ander bloedselle (Schüpbach, 1989:39; Murray et al., 1989:636-642).

Die finale fase van VIGS is noodwendig die dood. Dit geld vir baba, kind en volwassene, ryk en arm, man en vrou, wit, geel, en swart! Op hierdie stadium geld dus nog: HIV-positief $=$ doodsvonnis.

\subsection{Proteīene van HIV met 'n moontlike direkte invloed op die liggaam}

Die reeds genoemde proteien gp120 bind aan CD4. Hierdie assosiasie mag 'n invloed uitoefen op die normale kommunikasie tussen selle waarby CD4 betrokke is. 
Dit is ook bekend dat die proteïen gp120 oor aminosuurvolgordes beskik wat deels ooreenstem met dié van neuroleukin, 'n groeifaktor met 'n verskeidenheid effekte op die liggaam, byvoorbeeld stimulering van B-selle tot teenliggaamsintese en senuweevesel-instandhouding. Dit is dus moontlik dat die teenwoordigheid van gp120 die oorsaak kan wees van die poliklonale B-sel aktivering en neurologiese afwykings wat by HIV-positiewe pasiënte voorkom (Gurney et al., 1986a:566-574; Gurney, 1986b:574581). ' $n$ Ander hipotetiese invloed spruit voort uit die feit dat daar gebiede in gp120 voorkom wat 'n groot mate van ooreenstemming met aminosuurvolgordes van IgG asook IgA vertoon (Maddon et al., 1986:333-348). Hierdie tipe homologie mag implikasies inhou tydens die opwek van neutraliserende teenliggame tydens infeksie en vaksinering asook die potensiaal tot ontlokking van outo-immune reaksies (immuunsisteem begin optree teen liggaamseie komponente).

Die proteien gp41 vorm ook deel van die HIV-kapsel. 'n Deel van hierdie proteïen word verteenwoordig by ander retrovirusspesies en vertoon die eienskap van immunosuppressie (onderdrukking van die immuunsisteem). Die aminosuurvolgorde van hierdie betrokke gedeelte stem ooreen met die aminosuurvolgorde van 'n gedeelte van 'n baie belangrike groeifaktor bekend as IL-2 (interleukin-2), 'n limfokien ('n proteïen wat deur limfosiete vrygestel word). IL-2 is onder andere betrokke by limfosiet-prolefirering. Die implikasie van hierdie homologie hou in dat die normale werking van IL2 onderdruk kan word deur gp41 en selfs aanleiding kan gee tot 'n outo-immune reaksie teen IL-2! (Bost et al., 1985:1373-1380; Reiher et al., 1986:9188-9192.)

Gp41 beskik ook oor 'n gebied wat ooreenstem met een van die selkommunikasie proteïene wat op die seloppervlak voorkom (MHC beta-ketting - een van die weefselverenigbaarheidsantigene) en as 'n natuurlike ligand (molekuul wat spesifiek bind aan 'n reseptor) van $\mathrm{CD} 4$ kan optree. Weer eens veroorsaak hierdie homologie dat die natuurlike kommunikasie tussen selle bederf word en uiteindelik tot 'n outo-immune reaksie aanleiding kan gee (Schüpbach, 1989:65).

Nog 'n HIV-proteïen, bekend as gp17, wat op die oppervlak van die virus voorkom, besit ' $n$ gedeelte wat homoloog is aan timosien-alfa $a_{1}$,' $n$ peptiedhormoon. Hierdie hormoon wat deur die timus geproduseer word, tree as 'n potente immunomodulator op en werk hoofsaaklik in op Th-selle. Van die belangrikste funksies van hierdie hormoon is die stimulering van die T-selle om IL-2 asook ander limfokiene te produseer. Die hormoon herstel ook Th-selfunksie sodat enige molekuul wat in hierdie interaksie tussenbeide tree, 'n direkte invloed op die immunsisteem sal uitoefen. Dit is dan ook presies wat waargeneem is by HIV-pasiente, naamlik dat hulle in sommige gevalle simptome vertoon wat ooreenstem met pasiënte met 'n timusdefek en derhalwe 'n immuunsisteemafwyking vertoon (die timusklier is verantwoordelik vir die ontwikkeling van $\mathrm{T}$-selle). Die afleiding kan dus gemaak word dat gp17 aan die timosien-alfa 
reseptor bind, maar omdat dit origens oor 'n ander struktuur beskik, vertoon dit nie biologiese aktiwiteit nie. Die normale hormonale werking word dus geblokkeer.

Die gedeeltelike ooreenstemming tussen gp17 en timosien-alpha kan ook tot 'n outoimmune reaksie aanleiding gee (Sarin et al., 1986:1135-1137; Schüpbach, 1989:65).

\section{DIAGNOSTIESE TEGNIEKE}

Verskeie tegnieke is reeds ontwikkel en beskikbaar op die mark as volledige toetsstelle (test kits). Twee beginsels van toetsing kan egter uitgesonder word, naamlik dié wat berus op die toets vir die teenwoordigheid van

* IgG teen HIV in die serum en

* die provirus in die geneliese materiaal van die sel.

Eersgenoemde beginsel vorm die basis van 'n aantal toetse, byvoorbeeld die sogenaamde ELISA (enzyme linked immunosorbant assay), westelike oordrag (Westem blot) en ander variasies daarvan. Alhoewel die beginsel waarop hierdie toetse berus gesofistikeerd en elegant is, is die metode eenvoudig en hoef die personeel wat betrokke is nie veel opleiding te ontvang nie.

Die tweede beginsel berus op die feit dat selle wat met die virus geïnfekteer is, noodwendig pro-virus of dan virus-DNA moet bevat. Aangesien daar HIV-peilers (gedeeltes van die HIV-genoom) beskikbaar is, kan laasgenoemde gebruik word om provirusse in selle van HIV-geïnfekteerde persone waar te neem. Hierdie tegniek is bekend as PCR (polymerase chain reaction) en is baie sensitief, sodat selfs een proviruskopie op hierdie manier waargeneem kan word (Bell, 1989:351-355). Die voordeel van hierdie tegniek is dat dit baie sensitief en ook onafhanklik van die aktiwiteit van die immuunsisteem is. Dit beteken dat persone wat geïnfekteer is, maar nog in die stadium voor sero-oorskakeling verkeer (window period) opgespoor kan word. Die nadeel is dat hierdie tegniek arbeidsintensief en duurder as die eersgenoemde toets is. Die toets vereis ook hoogs opgeleide personeel en uitgebreide laboratoriumfasiliteite. Hierdie toetsmetode kan dus nog nie op 'n roetinebasis gebruik word nie.

\section{ONTSMETTING}

Omdat die virus in enige liggaamsvloeistof van 'n HIV-geïnfekteerde persoon kan voorkom, mag die vraag ontstaan hoedanig besmette areas of meublement hanteer moet word. 
Die belangrikste om te onthou is om uiters versigitg te wees vir velkontak met enige vloeistof soos byvoorbeeld bloed. Wanneer sodanige kontak onvermydelik is, moet handskoene gebruik word wat na gebruik deur hittebehandeling vernietig moet word. Besmette oppervlakke kan ontsmet word met huishoudelike bleikmiddels wat hipochloried as aktiewe bestanddeel bevat (Jik onder andere). Hierdie huishoudelike middels bevat gewoonlik $1 \%$ hipochloried en kan derhalwe twee keer verdun word, dit wil sê een volume bleikmiddel plus een volume water (1 koppie +1 koppie). Sterker bleikmiddels kan dienooreenkomstig meer verdun word. Was die oppervlakke deeglik en indien moontlik, laat die bleikmiddel vir 'n tyd (ongeveer 30 minute) in kontak met die omgewing. Hipochloried is 'n baie effektiewe ontsmettingsmiddel veral vir HIV (Spire et al., 1984:899-901). Ander chemiese middels soos 2\% glutaraldehied en 70\% etanol is ook ondersoek en dit word aanbeveel dat dié middels minstens 'n uur lank in kontak met die voorwerp moet wees.

\section{VAKSINERING EN TERAPIE}

"Vaccination campaigns rid the world of smallpox and, it is hoped, will before long do the same for polio. So far the complexities of the HIV virus have defied scientists efforts to produce a vaccine." Hierdie uitspraak van dr. José Esparza, hoof van Biomediese navorsing van die Wêreldgesondheidsorganisasie, en wat spesifiek gemoeid is met 'n wêreldprogram oor VIGS, is veelseggend ten opsigte van die stand van sake rakende vaksinering vir VIGS (Esparza, 1989:10-11). Hierdie navorser voorsien dat 'n algemene en bruikbare vaksien nie binne die volgende tien jaar beskikbaar gestel sal word nie. Navorsing word egter naarstiglik op hierdie gebied gedoen en verskeie preparate is op die oomblik in die eerste fase van ondersoek.

Vaksiene tree op as aktiveerders om die geheue van die immunsisteem van die liggaam aan te skakel. Die eerste konfrontasie tussen die lisyaam en 'n antigeen betrap as 't ware die liggaam onverhoeds sodat dit sewe tot tien dae vir die liggaam neem om uiteindelik ' $n$ infeksie te bowe te kom. Die belangrikste is egter dat nadat die immuunsisteem geheueselle van beide $T$ - en B-limfosiettipes gevorm het as gevolg van hierdie eerste konfrontasie met 'n antigeen, die opvolgende konfrontasie deur dieselfde antigeen vinnig en effektief afgeweer sal word. Die doel van die vaksien is dus om die antigeen in 'n skadelose vorm, bekend as 'n immunogeen, toe te dien sodat die liggaam geaktiveer kan word.

'n Aantal verskillende strategieë dien as uitgangspunt in die ontwikkeling van vaksiene.

- Die gebruik van geïnaktiveerde, intakte HIV-virusse. 
- Die gebruik van HIV-subeenheidspesifieke virusproteïene soos gp160, gp120, gp41, gp17 en die suikergroepe gekoppel aan die proteiene.

- Die gebruik van gekloneerde preparate (gedeeltes van die virusgenoom word in 'n bakterie ingebou wat dan in die laboratorium gekweek word om groot hoeveelhede suiwer virusproteïen van die navorser se eie keuse te vervaardig).

- Die gebruik van 'n vektor, soos die vaccinia-virus wat oor genetiese inligting van HIV beskik (deur geenmanipulering ingevoeg), wat dan na infeksie van 'n persoon nie net sy eie proteiene nie, maar ook die ingeboude gene soos in hierdie geval, HIV-gene, tot uitdrukking bring.

- Die gebruik van epitope. Hierdie benadering sluit in dat spesifieke fragmente van die verskillende proteiene ondersoek word vir immunogenisiteit. Welslae is dan ook behaal deurdat epitope wat sowel B-sel as T-selreaksies ontlok, geïdentifiseer is. Die sogenaamde V3-gebied wat aminosure 303 tot 321 van die virusproteïen gp120 insluit, induseer neutraliserende teenliggame teen HIV terwyl envT1 en envT2, wat ook aminosuurvolgordes binne gp120 verteenwoordig, Th-sel response opwek. Sintetiese peptiede wat 'n hibried is van hierdie twee epitope het dan ook 'n neutraliserende reaksie in proefdiere ontlok. Hierdie benadering hou beloftes vir toekomstige vaksiene in, maar dit is ongelukkig nog in 'n eksperimentele fase. Verskeie probleme moet nog te bowe gekom word en navorsers reken dat indien die vaksien so belowend bly, eksperiment op mense oor twee jaar kan begin sodat ' $n$ moontlike vaksien teen die einde van die eeu op die mark geplaas mag word (Leclerc, 1990:428-432; Brown, 1990a:24; Brown, 1990b:37).

In al vyf bogenoemde gevalle word die immuunsisteem dus met die HIV of gedeeltes daarvan gekonfronteer en hopelik geaktiveer sonder dat die virus self kan verbyglip en ' $n$ infeksie kan bewerkstellig.

Belangrike faktore wat by die gebruik van virussubeenhede as vaksiene in gedagte gehou moet word, is dat die proteiene wat gekies word van so 'n aard moet wees dat teenliggame wat daaraan bind ' $n$ wesenlike neutraliserende uitwerking en ook'n anti-infektiewe toestand sal bewerkstellig. Dit is baie belangrik om in gedagte te hou dat onder normale omstandighede die immuunsisteem na HIV-infeksie ook aangeskakel word om teenliggame teen die virus te vervaardig. Dit is juis vir die teenwoordigheici van hierdie teenliggame wat tydens 'n VIGS-toets getoets word. Meer nog, die liggaam wen ook aanvanklik die infeksie, selfs vir jare, maar uiteindelik stort die immuunsisteem in duie en ontstaan VIGS. Enkele redes hiervoor is eerstens dat die virus in staat is om weg te kruip in die vorm van 'n provirus. In hierdie vorm kan die immuunsisteem nie aangeskakel word nie. 
Tweedens is dit waargeneem dat die virus ook binne vesikels binne die sitoplasma van 'n geïnfekteerde sel kan voorkom. In hierdie geïsoleerde vorm is die virus ook onbereikbaar vir die immunnsisteem en kan selfs van sel tot sel oorgedra word sonder dat dit ooit vry voorkom. In sulke selle kom daar nie eers virusproteïene in die membraan voor nie. Derdens is dit belangrik om te onthou dat die selle wat die teiken van HIV is, juis dié is wat 'n sleutelrol in die immunsisteem speel, naamlik die Th-selle. Vierdens moet gewaak word teen moontlike outo-immunereaksies. Soos reeds beskryf, beskik van die HIV-subeenhede oor gedeeltes wat struktureel ooreenstem met sommige van die proteïene in die liggaam self. Vyfdens kan die hoë mutasiefrekwensie genoem word wat die virus gevolglik gedurig laat verander. Sodra die immuunsisteem teenliggame teen 'n komponent vervaardig het, verander die virus sy voorkoms en gaan ongestoord met sy destruktiewe infeksie voort.

- 'n Strategie bekend as intrasellulêre immunisering moet ook hier genoem word. Hierdie benadering is gebaseer op die gebruik van virusse met mutasies in strategiese genoomgebiede. Wanneer so 'n mutant eksperimenteel toegelaat word om 'n sel gelyktydig met die wilde tipe HIV te transfekteer, (ko-transfeksie - 'n spesiale tegniek waartydens DNA met manipulasie in die sel ingedra word) onderdruk die mutant die replikasie van die wilde tipe.

Hierdie metode word beskou as ' $n$ prototipe in die ontwikkeling van die antiretrovirale strategie en staan bekend as intrasellulère immunisering (Trono et al., 1989:113-120; Green et al., 1989:215-223).

- 'n Laaste strategie is die ontwikkeling van teenliggame teen CD4 (dit is die proteïen walaraan die virus deur middel van byvoorbeeld gp 120 bind) en hierdie teenliggame dien op hulle beurt as antigene waarteen 'n tweede stel teenliggame gevorm kan word. Die teorie van hierdie benadering is dat wanneer teenliggame teen 'n spesifieke molekuul gevorm word, die bindingspunte van die teenliggaam presies komplementêr is aan die gedeelte van die molekuul waaraan die betrokke teenliggaam bind. Die vorm van die bindingspunt van die teenliggaam staan dan as 'n idiotipe bekend en die idiotipe is spesifiek vir elke tipe immunoglobien. Wanneer so 'n teenliggaam nou as liggaamsvreemd toegedien word sodat teenliggame teen hierdie teenliggaam gevorm word, sal daar ook teenliggame teen die bindingspunt gevorm word sodat hierdie sogenaamde teen-teenliggame oor bindingspunte beskik wat komplementêr is aan dié van die teenliggaam waarteen dit gevorm is. Dit beteken dat die bindingspunt van die teen-teenliggaam ooreen sal stem met die oorspronklike molekuul wat as antigeen gedien het. Hierdie teenliggame staan as anti-idiotipes bekend. Anti-idiotipes behoort dan ook teoreties in staat te wees om die antigeen te kan vervang en dus met die teenliggaam te kan verbind wat spesifiek met die antigeen kan verbind. In die geval van HIV verbind gp 120 van die virus met 
CD4. Die anti-idiotipe vir CD4 sal dus dieselfde struktuur as 'n gedeelte van CD4 besit en in staat wees om met gp120 te verbind wat aan dieselfde punt van CD4 verbind. Op hierdie wyse word alle gp120-molekule geblokkeer met anti-idiotipes sodat dit nie met CD4-reseptore kan verbind en uiteindelik die sel kan infekteer nie (Matthews \& Bolognesi, 1988:98-105; Hansen et al., 1989:635-641; Schüpach, 1989:72-75; Bolognesie, 1989:1233-1234).

Op grond van die redes wat reeds genoem is, is daar nog nie 'n suksesvolle vaksien beskikbaar nie en lyk die prentjie ook nie rooskleurig wat hierdie aspek van die terapie/voorkoming betref nie - nie eers die onlangse bekendmaking van die Franse groep onder leiding van dr. D. Zagury dat hulle besig is om 'n potensiële vaksien te evalueer, hou noemenswaardige belofte in nie. Hierdie vaksien is nog maar in die eerste fase van eksperimentering en moet nog eers getoets word vir menslike gebruik. Die volgende fases (fase 2 en 3) sal eers uitwys of die vaksien enige werklike immuniseringswaarde besit. By VIGS-pasiënte word in elk geval teenliggame teen die virus gevorm, maar die teenliggame is nie in staat tot die volledige neutralisering van die VIGS-virus nie (Baltimore \& Feinberg, 1989:1673-1675). Of die immuniseringsvaksien dit sal kan doen is 'n ope vraag! Op die oomblik word die hoop nog in 'n groot mate gevestig op die ontwikkeling van geskikte chemiese middels soos AZT-verwante stowwe (vgl. Van der Schyf, 1990)

\section{BERADING}

Met geen hoop op genesing, die vooruitsig van 'n verskriklike lyding en daarmee saam die amper noodwendige verwerping deur familie en vriende, word 'n somber prentjie geskep vir 'n persoon wat pas die doodsvonnis ontvang het, naamlik "u bloed is getoets en dit is HIV-positief!" Om hierdie rede is dit van groot belang dat mense wat hulle self wil laat toets, vooraf voorberei moet word op die moontlike implikasie en komplikasies. Net so, of selfs belangriker, is die berading nadat 'n persoon die tyding ontvang het. Indien oppervlakkige berading geskied, help dit slegs om die toestand te vererger en gebeur dit selfs dat van hierdie pasiënte selfmoord of selfs moord pleeg deurdat hulle opsetlik ander mense besmet met die virus (Council Report, 1988:1360-1361; Marzuk et al., 1988:1333-1337). Dit is belangrik om te onthou dat VIGS neurologiese afwykings kan insluit (Schüpbach, 1989:44) en wanneer 'n persoon met 'n misplaaste wrok teen die samelewing rondloop, is hy tot enigiets in staat. Tydens onlangse konsultasies met verskeie groot maatskappye het dit duidelik geblyk dat die berading van werkers in verband met HIV-infeksie 'n toenemende belangrike rol speel.

Dit is op hierdie gebied waar aan die behoeftes van die geïnfekteerde persoon aandag gegee moet word. Dit sluit in dat die persoon met werklike empatie behandel moet 
word. Ook beteken dit dat die persoon met die volle werklikheid gekonfronteer moet word sodat hy die volle implikasie van sy optrede besef en verstaan. Daarmee saam is dit belangrik dat indien die infeksie die gevolg is van 'n promiskue lewe, so 'n persoon tot die volle besef van sy sonde gebring moet word. Sonde beteken "om die doel te mis" (Brown, 1986:177). So 'n persoon het die doel wat God met sy lewe het, gemis. Dit mag hard klink, maar die feit is dat 'n mens alleen by die kruis op Golgota kan uitkom en volkome vryspraak en versoening kan ontvang indien hy homself in die oë kyk en sy werklike nood besef. Die prys is reeds volledig betaal en die uitnodiging staan vas "O almal wat dors het kom na die waters, en wie geen geld het nie, kom, koop sonder geld en sonder prys wyn en melk!" (Jes. 55, ou vertaling). (Vir 'n meer breedvoerige bespreking van dié aspek vgl. de Bruyn, 1990).

\section{VOORKOMING}

Voorkoming is beter as genesing, is 'n spreekwoord wat nog nooit so toepaslik was as juis in hierdie VIGS-drama en veral nou nie.

Dit is onrusbarend om te sien en te hoor hoe al meer jongmense (selfs op laerskoolvlak) nie net seksueel aktief raak nie, maar ook by homoseksualisme betrokke raak. Hiermee saam het onlangse ondersoeke na beweerde kindermolestering die publiek aangegryp en nóg 'n euwel blootgelè. 'n Studie in Amerika het aan die lig gebring dat uit 'n totaal van 561 seksuele oortreders wat ondervra is, elke pedofiel wat manlike slagoffers (nie-bloedskande gevalle) betrek het, gemiddeld 150,2 seuns gemolesteer het. Die gemiddelde aantal parafiliese dade binne dieselfde kategorie was 281,7 per molesteerder (Fuller \& Bartucci, 1988:2235-2236). Kinders wat by hierdie tipe van seksmisdrywe betrek word, verloor in baie gevalle hulle selfrespek en gly maklik in prostitusie of 'n los lewe in. Hierdie tipe lewe skep 'n ideale geleentheid vir HIV. infeksie.

Wat kan ons aan hierdie VIGS-probleem doen? Die heel belangrikste taak, en wat allerweë as die eerste uitgangspunt beskou word, is opvoeding en dan spesifiek dié van jongmense (Ferguson, 1989:12-13; Mann, 1989:6-9; Netter, 1989:25-26). Ongelukkig is dit so dat die wèreld veilige seks propageer in plaas van regte verhoudinge, volgens die Skrif. Eersgenoemde het wel 'n effek maar is tydelik en bied nie 'n oplossing nie. In teenstelling hiermee kan ons kinders juis weerbaar gemaak word indien hulle verstaan waarom seks ingestel is en wat die doel van die huwelik is (Ef.5). 


\section{BIBLIOGRAFIE}

ARTHOS, J. DEEN, K.C., CHAIKIN, M.A. FORNWALD, J.A., SATHE, G., SATTENTAU, QJ., CLAPHAM, P.R., WEISS, R.A., McDOUGAL, J.S., PIETROPAOLO, C., AXEL, R., TRUNEH, A, MADDON, P.J. \& SWEET, R.W. 1989. Identification of the residues in human CD4 critical for binding of HIV. Cell, 57:469-481.

BALTIMORE, D. \& FEINBERG, M.B. 1989. HIV revealed. The New England Journal of Medicine, 321(24):1673-1675.

BELL, J. 1989. The polymerase chain reaction, Immunology Today, 10(10):351-355.

BOLOGNESI, D.P. 1989. Progress in vaccines against AIDS. Science, 246:1233-1234.

BOST, K.L., SMITH, E.M. \& BLALOCK, J.E. 1985. Regions of complementarity between the messenger RNAs for epidermal growth factor, transferrin, interleukin-2 and their respective receptors. Biochemical and Biophysical Research Communications, 128(3):1373-1380.

BOWERMAN, B., BROWN, P.O., BISHOP, J.M. \& VARMUS, H.E. 1989. A nucleoprotein complex mediates the integration of retroviral DNA. Genes and Development, 3:469-478.

BRADBEER, C.S. 1989. Mothers with HIV. British Medical Joumal, 299:806-807.

BROWN, C. 1986. The New International Dictionary of New Testament Theology, Volume 3. Grand Rapids, Michigan : Zondervan Publishing House.

BROWN, P. 1990a. French institute claims progress with AIDS vaccine. New Scientist, 126(1715):24.

BROWN, P. 1990b. A vaccine ready by the end of the decade. New Scientist, 126(1723):37

COUNCIL REPORT, 1988. Ethical Issues Involved in the Growing AIDS Crisis. Journal of the American Medical Association, 259(9):1360-1361.

CROWELL, R.L. \& LANDAU, B.J. 1983. Receptors in the initiation of picornavirus infections. Comprehensive Vinology, 18:1-42

CULLEN B.R. \& GREENE, W.C. 1989. Regulatory pathways governing HIV-1 replication. Cell, 58:423. 426.

CURTIS, H., LAWRENCE, C. \& TRIPP, J. 1989. Tecnage sexuality: implications for controlling AIDS. Anchives of Disease in Childhood, 64:1240-1245.

DALGLEISH, A.G., BEVERLEY, P.C.L., CLAPHAM, P.R., CRAWFORD, D.H., GREAVES, M.F \& WEISS, R.A. 1984. The CD4 (T4) antigen is an essential component of the receptor for the AlDS retrovirus. Nature, 312:763-766.

DE BRUYN, P.J. 1990. VIGS en menslike gedrag: 'n teologies-etiese besinning. (Referaat gelewer tydens 'n VIGS -inliglingsdag deur die PU vir CHO, Potchefstroom.)

DESROSIERS, R.C. 1988. Simian immunodeficiency viruses. Annual Review of Microbiology, 42:607625.

DOUGHERTY, J.P. \& TEMIN, H.M. 1988. Determination of the rate of base-pare substitution and insertion mutations in retrovirus replication. Joumal of Virology, 62:2817-2822.

ENSOLI, B., LUSSO, P., SCHACHTER, F., JOSEPHS, S.F., RAPPAPORT, J., NEGRO, F, GALLO, R.C. \& WONG-STAAL, F. 1989. Human herpes virus-6 increases HIV-1 expression in co-infecled T-cclls via nuclear factors binding to the HIV-1 enhancer. The Embo Joumal, 8(10):3019-3027.

ESPARZA, J. 1989. Prospects for a vaccine. World Health: 10-11, Oct.

ESSEX, M.\& KANKI, PJ. 1988. The origins of the AIDS Virus. Scientific American: 259(4):44-51

FERGUSON, J. 1989. AIDS and young people. World Health: 12-13, Oct.

FISCHER, A.G., ENSOLI, B., LOONEY, D., ROSE, A., GALLO, R.C., SAAG, M.S., SHAW, G.M., HAHN, B.H. \& WONG-STAAL, F. 1988. Biologically diverse molecular variants within a single HIV-1 isolale. Nature, 334:444.447.

FULLER, A.K. \& BARTUCCI, RJ. 1988. HIV transmission and childhond sexual abuse. Joumal of American Medical Association, 259(15):2235-2236.

GIRARD, M. 1988. The Pastcur Institute's contributions to the field of virology. Annual Review of Microbiology, 42:745-763. 
GREENE, W.C. BöHNLEIN, E. \& BALLARD, D.W. 1989. HIV-1, HTLV-1 and normal T-cell growth: iranscriptional strategies and surprises. Immunology Today, 10(8):272-277.

GREEN, M ISHINO, M. \& LOEWENSTEIN, P.M. 1989. Mutational analysis of HIV-1 Tat minimal domain peptides: identification of trans-dominant mutants that suppress HIV-LTR-driven gene expression. Cell, 58:215-223.

GURNEY, M.E. HEINRICH, S.P., LEE, M.R. \& YIN, H-S. 1986a. Molecular cloning and expression of ncuroleukin, a neurotrophic factor for spinal and sensory neurons. Science, 234:574-581.

GURNEY, M.E., APATOFF, B.R., SPEAR, G.T., BAUMEL, MJ., ANTEL, J.P., BANIA, M.B. \& REDER, A.T. 1986b. Ncuroleukin: a Lymphokine product of lectin-stimulated T cells. Science, 234:566-574

HANSEN, J.S., NIELSEN, C.M., NIEISEN, C. HEEGAARD, P., MATHIESEN, L.R. \& NIELSEN, J.O. 1989. Correlation between carbohydrate structures on the envelope glycoprotein gp120 of HIV-1 and HIV-2 and syncytium inhibiton with lectins. AIDS, 3:635-641.

HURLEY, T.R., LUO, K. \& SEFTON, B.M. 1989. Activators of protein kinase C induce dissociation of CD4, but not CD8, from p56lck. Science, 245:407-409.

JANEWAY, Jr., C.A. 1989. The role of CD4 in T-cell activation: accessory molecule or co-receptor? Imminology Today, 10(7):234-238.

JERNE, N.K. 1973. The immune system. Scientific American, 229(1):52-60.

JONES, KA., LUCIW, P.A. \& DUCHANGE, N. 1988. Structural arrangements of transcription control domains within the 5'-untranslated leader regions of the HIV-1 and HIV-2 promotors. Genes and Development, 2:1101-1114.

JUPP, P.G. \& LYONS, S.F. 1987. Experimental Assessment of Bedbugs (Cimex lectularius and Cimex hemipterus) and mosquitocs (Aedes acgypti formosus) as vectors of human immunodeficiency virus. $A I D S, 1: 171-174$

LANDOR, M., HARISH, Z. \& RUBINSTEIN, A. 1989. Human immunodeficiency virus transmission. Is the integument a barrier? American Joumal of Medicine, 87(4):489.

LARDER, B.A. \& KEMP, S.D. 1989. Multiple mutations in HIV-1 reverse transcriptase confer highlevel resistance to zidovudine (AZT). Science, 246:1155-1158.

LECLERC, C. 1990. Vaccination against HIV and SIV. Cument Opinion in Immunology, 2:428-432.

MADDON, P.J., DALGLEISH, A.G., McDOUGAL, J.S., CLAPHAM, P.R., WEISS, R.A.\& AXEL, R. 1986. The T4-gene encodes the AIDS virus receptor and is expressed in the immune system and the brain. Cell, 47:333-348.

MADDON, P.J., McDOUGal, J.S., ClAPHAM, P.R., DAlgleish, A.G., JAMAL, S., WEISS, R.A. \& AXEL, R. 1988. HIV infection does not require endocytosis of its receptor, CD4. Cell, 54:865-874

MADDON, PJ., LITTMAN, D.R., GODFREY, M., MADDON, D.E., CHESS, L. \& AXEL, R. 1985 The isolation and nucleotide sequence of a cDNA encoding the T-cell surface protein T4: $A$ new member of the immunoglobullin gene family. Cell, 42:93-104.

MANN, J. 1989. Global AIDS into the 1990 s. World Health: 6-7, Oct

MARZUK, P.M., TIERNEY, H., TARDIFF, K., GROSS, E.M., MORGAN, E.B., HSU, M. \& MANN J.J. 1988. Increased risk of suicide in persons with AIDS. Joumal of American Medical Association, 259(9): 1333-1337.

MATTHEWS, T J. \& BOLOGNESI, D.P. 1988. Aids vaccines. Scientific American, 259(4):98-105.

MEYERHANS, A., CHEYNIER, R., ALBERT, J., SETH, M., KWOK, S., SNINSKY, J., MORFELDT-MANSON, L., ASJö, B. \& WAIN-HOBSON, S. 1989. Temporal fluctuations in HIV quasispecies in vivo are not reflected by sequential HIV isolations. Cell, 58:901-910.

MURRAY, P.A., GRASSI, M. \& WINKLER, J.R. 1989. The microbiology of HIV-associatcd periodontal lesions. The Joumal of Clinical Periodontology, 16:636-642.

NETTER, T, 1989. World AIDS Day. World Health: 25-26, Oct. 
RAMIREZ, G., BRAATHEN, L.R., KUNZE, R.O.F. \& GELDERBLOM, H. 1988 . In vitro infection of human epidermal Langerhans cells with HIV. Advances in Experimental Medicine and Biology, 237:901-905.

REIHER, W.E., BLALOCK, J.E. \& BRUNCK, T.K. 1986. Sequence homology between acquired immunedeficiency syndrome virus envelope protein and interleukin-2. Proceedings of the National Academy of Sciences U S.A., 83:9188-9192.

ROITT, I., BROSTOFF, J. \& MALE, D. 1989. Immunology. Second edition. London : Gower Medical Publishing.

ROSENBERG, Z.F. \& FAUCI, A.S. 1988. Immunopathogenic Mechanisms in Human Immunodefiency Virus (HIV) Infections. Annals of the New York Academy of Sciences, 546:164-174.

SARIN, P.S., SUN, D.K, THORNTON, A.H, NAYLOR, P.H. \& GOLDSTEIN, A.L. 1986. Neutralization of HTLV-III/LAV replication by antiserum to thymosin-alpha1. Science, 232:1135-1137

SATTENTAU, Q.J. \& WEISS, R.A. 1988. The CD4-antigen. Physiological Ligand and HIV receptor. Cell, 52:631-633.

SCHüPBACH, J. 1989. Human retrovirology: facts and concepts. Cument Topics in Microbiology and Immunology, 142:1-108.

SPIRE, B., MONTAGNIER, L. BARRé-SINOUSSI, F. \& CHERMANN, J.C. 1984. Inactivation of lymphadenopathy associated virus by chemical disinfectants. The Lancel, 20:899-901, Oct.

STEIN, B.S., GOWDA, S.D., LIFSON, J.D., PENHALLOW, R.C., BENSCH, K.G. \& ENGLEMAN, E.G. 1987. pH-Independent HIV cntry into CD4-positive $\mathrm{T}$ cells via virus envelope fusion to the plasma mcmbrane. Cell, 49:659-668.

TRONO, D., FEINBERG, MB. \& BALTIMORE, D. 1989. HIV-1 Gag mutants can dominantly interfere with the replication of the wild-lype virus. Cell, 59:113-120.

VAN DER SCHYF, C.J. 1990. Die behandeling van VIGS - genecsmiddels en vaksiene. Wat hou die toekoms in? (Referaat gelewer tydens 'n VIGS-inligtingsdag deur die PU vir CHO, Potchefstroom)

VARMUS, H. 1988. Regulation of HIV and HTLV gene expression. Genes and Development, 2:10551062

WEBB, PA., HAPP, C.M., MAUPIN, G O., JOHNSON, B.J.B., OU, L. \& MONATH, T.P. 1989. Potential for insect transmission of HIV. The Joumal of Infectious diseases, 160(6):970-977 
